\title{
Epigenetic responses and the developmental origins of health and disease
}

\author{
Dipali Goyal, Sean W Limesand* and Ravi Goyal \\ School of Animal and Comparative Biomedical Sciences, College of Agriculture and Life Sciences, University of Arizona, Tucson, Arizona, USA
} Correspondence should be addressed to R Goyal: rgoyal@live.com

This paper is part of a thematic section on 30 Years of the Developmental Endocrinology of Health and Disease. The guest editors for this section were Sean Limesand, Kent Thornburg and Jane Harding

*(S W Limesand was not involved in the editorial or review process for this paper, on which he is listed as an author)

\begin{abstract}
Maternal and paternal factors influence offspring development and program its genome for successful postnatal life. Based on the stressors during gestation, the pregnant female prepares the fetus for the outside environment. This preparation is achieved by changing the epigenome of the fetus and is referred to as 'developmental programming'. For instance, nutritional insufficiency in utero will lead to programming events that prepare the fetus to cope up with nutrient scarcity following birth; however, offspring may not face nutrient scarcity following birth. This discrepancy between predicted and exposed postnatal environments are perceived as 'stress' by the offspring and may result in cardiovascular and metabolic disorders. Thus, this developmental programming may be both beneficial as well as harmful depending on the prenatal vs postnatal environment. Over the past three decades, accumulating evidence supports the hypothesis of Developmental Origin of Health and Disease (DOHaD) by the programming of the fetal phenotype without altering the genotype per se. These heritable modifications in gene expression occur through DNA methylation, histone modification and noncoding RNA-associated gene activation or silencing, and all are defined as epigenetic modifications. In the present review, we will summarize the evidence supporting epigenetic regulation as a significant component in DOHaD.
\end{abstract}

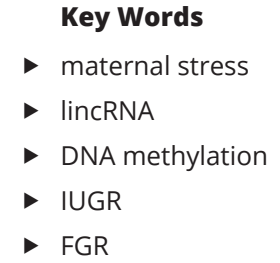

Journal of Endocrinology (2019) 242, T105-T119

\section{Introduction}

Epidemiological studies in humans and experimental studies in laboratory animals have demonstrated a relation between intrauterine fetal stressors and the development of diseases in the adult offspring. These fetal stressors include maternal food excess and deprivation, hypoxia, drug addiction, alcohol and emotional stress (Limesand et al. 2006, Jansson \& Powell 2007, Gluckman et al. 2008, Hanson \& Gluckman 2008, Borengasser et al. 2013, Goyal \& Longo 2013, Jang et al. 2015, Agarwal et al. 2018,
Ducsay et al. 2018, Lecoutre et al. 2018). A factor that has received increasing attention, in this regard, is the idea of 'developmental programming' during fetal life, as a consequence of maternal stress or placental complications (Barker 2002, 2008, Barker et al. 2007, Goyal et al. 2009, Boehmer et al. 2017). One explanation behind developmental programming is that mothers prepare their babies to survive in the outside world. Based on the prenatal environment, fetal growth is modified 
to cope with the expected postnatal environment. For instance, maternal undernutrition will prepare the fetus for nutritional scarcity postnatally. This 'developmental programming' equips the organism with the capacity to store extra nutrition, if available, which may lead to obesity if dietary conditions are plentiful. Similarly, future development of diabetes mellitus is another mechanism to cope up with nutritional scarcity or overabundance because adaptations in glucose homeostasis can also be programmed in utero. Other stressors such as maternal obesity and overfeeding lead to adaptations in metabolism and adiposity in the offspring.

Several studies in humans and experimental animals have demonstrated that early growth restriction due to antenatal maternal stress or placental insufficiency can result in the development of hypertension, stroke, depression, schizophrenia, obesity, diabetes and other conditions (Fig. 1) (Hoek et al. 1996, Susser et al. 1998, Vickers et al. 2000, Vehaskari et al. 2001, Brawley et al. 2003, Goyal et al. 2010, Goyal \& Longo 2013, Longo et al. 2014). The placenta forms the connection between mother and fetus and is responsible for the transfer of nutrients and oxygen. The placenta is also an important endocrine organ (Evain-Brion \& Malassine 2003).
Placental hormones play an essential role in fetal development and are a significant factor in programming. For instance, maternal stress has been shown to reduce maternal progesterone concentrations and methylate placental heme oxygenase 1 promoter (Solano et al. 2015). Reduction in heme oxygenase 1 expression slows fetal growth through immune-related actions, illustrating endocrine-related epigenetic changes due to maternal stress. Thus, changes in placental hormone initiate mechanisms that initiate a cascade of events that cause fetal growth restriction and may result in developmental programming. Of note, placental pathologies (such as placental insufficiency, or abnormal placental growth and insertion) may lead to fetal stress and developmental programming without maternal stress.

The question arises, how can a stressor during antenatal life be linked to so many multifaceted disorders in the adult? It is possible that maternal stress programs the embryonic cell mass; these cells then migrate and lead to the formation of the various organs with abnormal cell metabolism. Altered 'programming' of these embryonic cells, may manifest as different clinical disorders through the life course of the individual. Furthermore, the precise

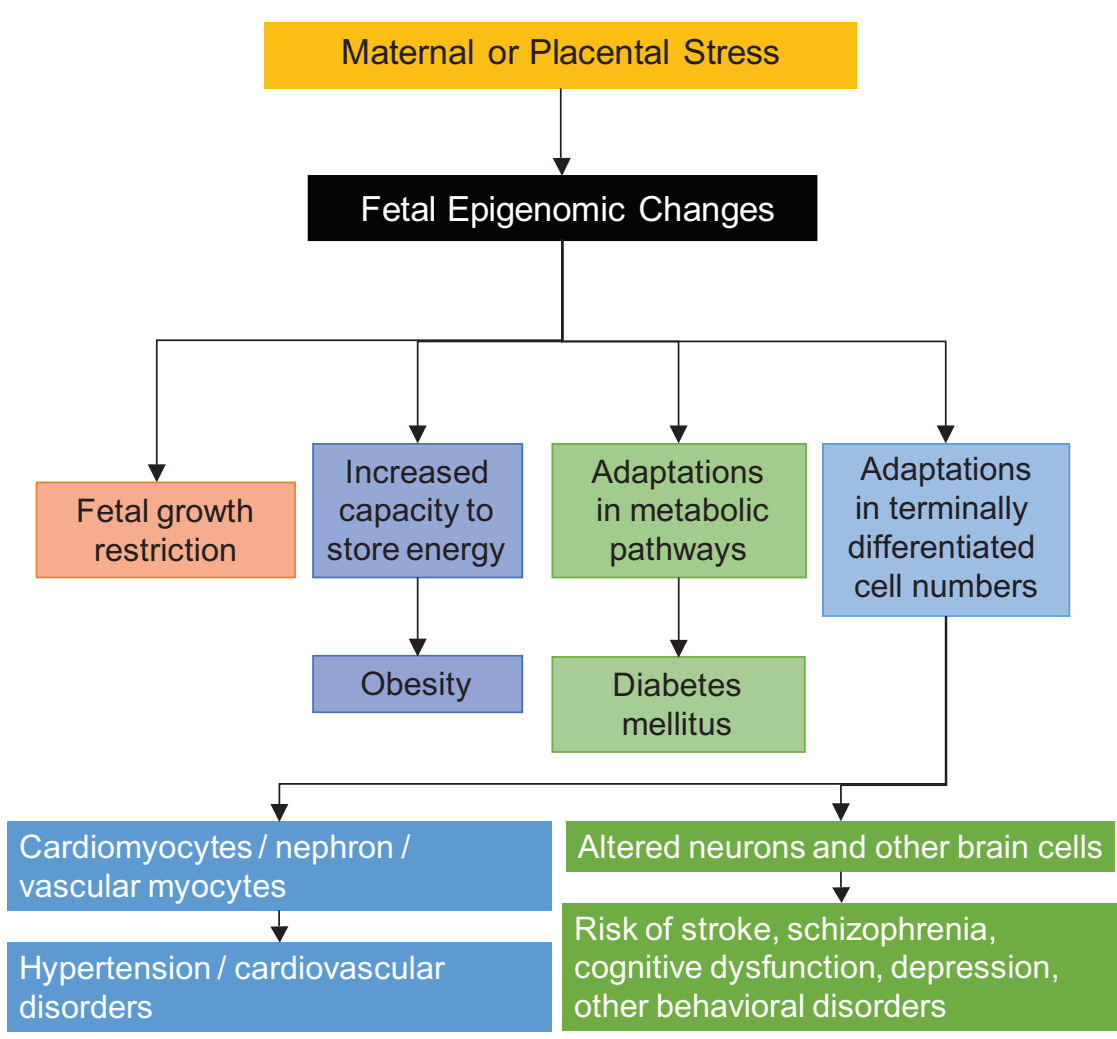

\section{Figure 1}

Maternal and placental stress-mediated changes in fetal epigenome responsible for developmental programming and differential adaptation responses in the fetus which can ultimately lead to phenotypic changes and disorders in adult offspring. 
timing and severity of the antenatal stress may make individuals susceptible to different disorders observed in the epidemiological studies by Barker and other groups. Importantly, the evidence demonstrates that developmental programming occurs from day 0 following fertilization. A study (Kwong et al. 2000) demonstrated that rat dams fed low-protein diet only during the preimplantation period following fertilization of the ovum ( $0-4.25$ days after mating), induced programming of altered birth weight and organ/body-weight ratios, accelerated postnatal growth rate and development of hypertension in both female or male offspring. Also, preimplantation embryos collected from dams after 0-4.25 days of maternal lowprotein diet (MLPD) displayed significantly reduced cell numbers in the inner cell mass (ICM) of the early blastocyst. This reduction in cell numbers was induced by a slower rate of cellular proliferation, rather than by increased apoptosis (Kwong et al. 2000). Thus, evidence indicates that maternal malnutrition during the periimplantation period can lead to long-term programming of postnatal growth and physiologic function.

\section{Mechanism of DOHaD}

Given these findings, it is crucial to elucidate the mechanisms of in utero programming of adult diseases. As we know, germ cells store information that has been handed down from their ancestors and that will be transmitted to their descendants. For the most part, this 'memory' is encoded in the sequence of nucleic acids that comprise the DNA of the genome, the genotype, which provides stability and accurate heritability from generation to generation. Much traditional research has explored the effects of the environment on germline mutations of the coding and promoter regions of genes. Alternatively, cells can inherit and transmit information that is not part of the genomic sequence. These 'epigenetic' (beyond conventional genetic) modifications involve the heritable transmission of the regulatory components of gene expression patterns that are passed to the daughter cells during cell divisions. The three important mechanisms known to regulate gene transcription epigenetically are DNA methylation, histone modifications and regulation by noncoding RNA (Fig. 2).

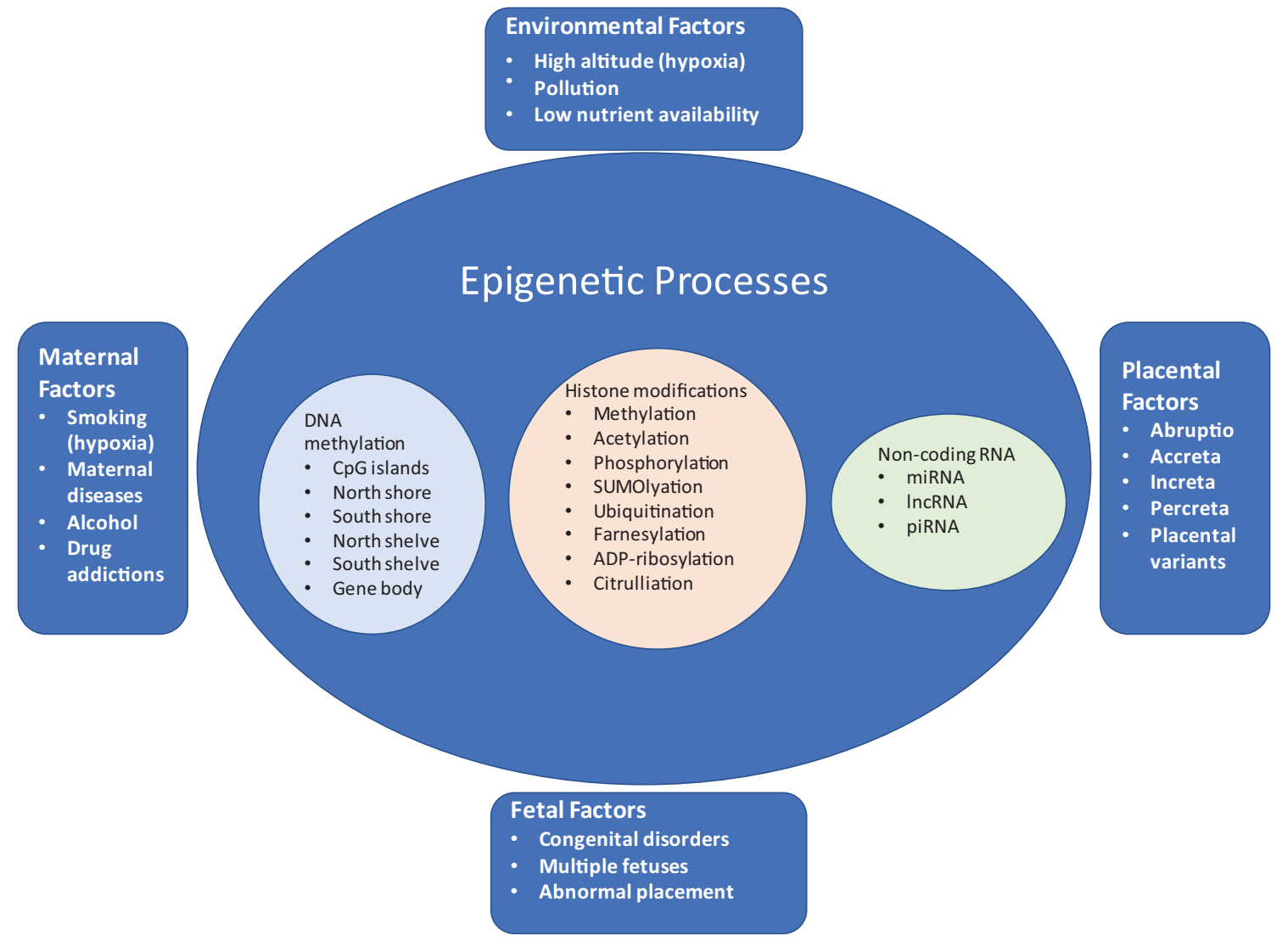

Figure 2

Various environmental, maternal, placental and fetal factors which can alter different epigenetic processes in the fetus. 


\section{DNA methylation and DOHaD}

Of all the epigenetic mechanisms, the most extensively studied is the control of gene expression by the alteration in the methylation of cytosine nucleotides in the promoter region of genes. Any cytosine in the DNA can be methylated; however, the chief regulatory cytosines are the ones which are adjacent to the guanosine. As the phosphodiester bonds join the nucleotides, these cytosine and guanosine are commonly referred to as $\mathrm{CpG}$ dinucleotides. Accumulating evidence during the past couple of decades indicate that DNA methylation and demethylation are key regulators of gene expression, as a consequence of environmentgene interactions. Methylation of cytosine changes DNAs hydrophobic property and inhibits its interaction with other transcription activators or suppressors. Hypomethylation of the cytosine bases in CpG islands located in a DNA promoter sequence allows increased (activates) gene expression, and hypermethylation results in decreased (silences) gene expression. Of note, DNA methylation in the gene body is associated with increased transcription (Yang et al. 2014). This can occur directly by inhibiting the binding of specific transcription activators or repressor and/or indirectly by recruiting methyl-CpG-binding proteins with repressive chromatin remodeling activities (Fig. 3).

Hypertension (Bogdarina et al. 2007, Goyal et al. 2009, 2013), type 2 diabetes mellitus (Williams et al. 2008), cancer (Schmutte \& Jones 1998), neurodegenerative disorders (Obeid et al. 2009) and other clinical conditions are related

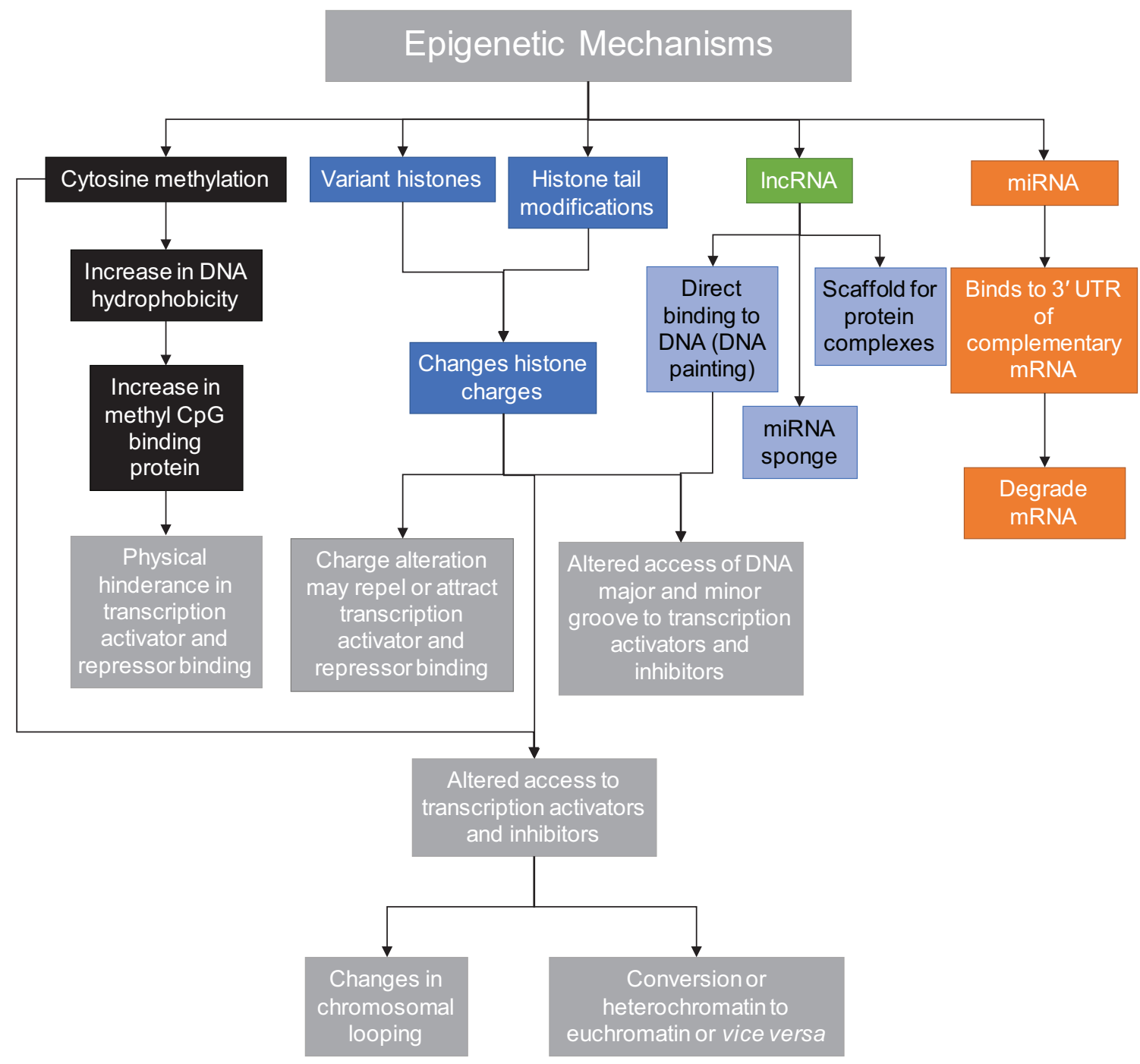

Figure 3

Different epigenetic mechanisms and underlying downstream processes which regulate gene expression. 
to altered DNA methylation. In the antenatal proteindeprived mouse fetus, we observed hypomethylation (activation) of the promoter region of the angiotensinI-converting enzyme (ACE) and increased ACE mRNA expression in the lung and brain (Goyal et al. 2010, 2011a). In hypertension ACE is an important enzyme target for pharmacological inhibitors (enalapril, lisinopril). Therefore, offspring from the antenatal protein-deprived mice also developed hypertension, hyperglycemia and obesity in adulthood, and the hypertension is associated with hypomethylation of the ACE gene promoter (Goyal et al. 2009, Goyal \& Longo 2013). Collectively, several experimental studies have established that environmental factors can lead to changes in DNA methylation, with altered gene expression. This is a mechanism in the pathogenesis of many disorders.

Enzymes critically associated with changes in DNA methylation are DNA methyltransferases (DNMT) and ten-eleven translocation methylcytosine dioxygenases (TET). DNA methyltransferases are a broad class of enzymes found in all groups of prokaryotic and eukaryotic organisms. There are four independently encoded mammalian DNMTs. DNMT1s are the classical maintenance methyltransferase, responsible for maintenance of methylation pattern during DNA replication (Bestor 2000). DNMT2 are now known to catalyze mainly RNA (Schaefer \& Lyko 2009, Jeltsch et al. 2017), whereas two other enzyme families, DNMT3a and DNMT3b (Leonhardt \& Bestor 1993, Poh et al. 2016), participate in the establishment of de novo methylation patterns during early embryonic development (Pradhan \& Esteve 2003). Importantly, DNMT1 knockdown is embryonic lethal in both heterozygous and homozygous mice (Li et al. 1992). However, both heterozygous Dnmt3a+/- and Dnmt3b+/- mice were apparently healthy and fertile. Homozygous Dnmt3a-/- mice appeared normal at birth but their postnatal growth is stunted, and these mice died at about 4 weeks of age (Okano et al. 1999). In contrast, homozygous Dnmt3b-/- mice are not viable and die around embryonic day 9.5 (Okano et al. 1999). Hypoxic stress is known to regulate DNMT expression (Watson et al. 2014, Hu et al. 2017); however, how much of hypoxia-mediated developmental programming is controlled by DNMTs is currently not known.

DNA methylation is reversible, and DNA can be demethylated by TET enzymes (Tahiliani et al. 2009, Guo et al. 2011, Mohr et al. 2011). These enzymes play an essential role in embryonic stem cell maintenance and ICM specification (Ito et al. 2010). There are three known
TET genes (TET1, TET2 and TET3). Genetic mutations of TET enzymes have demonstrated that TET1 and TET2 homozygous knockout mice are viable; however, TET1-knockout mice have a small body size (Dawlaty et al. 2011, 2013). Double knockout of both TET1 and TET2 genes in mice, increased their DNA methylation status and abnormal methylation was observed at various imprinted loci. Moreover, a small number of these double TET1 and 2-knockout mice demonstrated mid-gestation abnormalities with perinatal lethality (Dawlaty et al. 2013). TET3 gene knockout in mice has shown that it localizes in both the maternal and paternal pronucleus and plays some role in active demethylation. However, the TET3 gene knockout had no significant effect on fertilization or other aspects of embryonic and fetal development, but it resulted in neonatal lethality. Although individual knockdown of TETs did not produce much impact on in utero development, the triple knockout of all the three TETs led to impaired embryonic stem cell differentiation and complete arrest of embryonic development (Dawlaty et al. 2014). Thus, these studies demonstrate the redundant nature of these enzymes and their mechanistic involvement in vital developmental processes. The effect of hypoxia on TET and its impact during development is not well studied, but the function of TET enzymes is significantly reduced under hypoxic conditions and are linked to various malignancies (Thienpont et al. 2016). Thus, it is entirely reasonable to speculate that intrauterine hypoxia may dysregulate TET activities and may be associated with developmental abnormalities. However, further investigation is required to know how fetal stressors affect changes in DNA methylation of particular loci.

One may argue, however, why is DNA methylation so important for developmental programming? Of great importance, after fertilization, and through the blastocyst stage, male DNA undergoes complete demethylation (Abdalla et al. 2009). Subsequently, the genome undergoes de novo remethylation process to establish the basic bimodal methylation pattern observed at the time of implantation. This methylation organizes a fixed expression pattern in the genome, by which tissue-specific genes are either activated or repressed (based on the tissue expression pattern), while the genes required in vital functions are active in all types of the cells. Deficiency in amino acids may interfere with genomic demethylation and de novo methylation. In animal models, genomewide demethylation is observed during early murine and bovine embryonic development, reaching a nadir at the blastocyst stage (Monk et al. 1987, Kafri et al. 1992). 
During this stage, the gametic methylation marks are erased (demethylation). Later, these are replaced with embryonic marks that are important for cellular differentiation and organismal development (Reik et al. 2001, Meehan 2003). Recent studies indicate that mechanisms for paternal DNA demethylation differ from those responsible for maternal genome demethylation. Moreover, the paternal genome is subjected to replication-independent, genome-wide active demethylation during the first few hours after fertilization (Mayer et al. 2000, Oswald et al. 2000). In contrast, the maternal genome maintains its methylation pattern until the beginning mitotic division stage, when both maternal and paternal genome undergo replication-dependent, passive demethylation due to the absence of DNMT1 (methylation maintenance enzyme). Furthermore, the maternal environment may modify the methylation at this stage, in an attempt to regulate fetal development in accordance with available nutrient and other conditions. The methylation marks may also be reprogrammed, so that the offspring may be prepared to face adverse conditions long after birth. As may be appreciated, many aspects of embryonic methylation and its regulation are unknown (Wilkins 2005, 2006). For instance, what are the effects of maternal stress on these processes and the resulting long-term sequelae?

DNA methylation has emerged as a primary epigenetic mechanism involved in DOHaD. Studies demonstrate that maternal stress leads to increased stress hormones such as a glucocorticoid and catecholamines (Jensen Pena et al. 2012). Our studies demonstrate that maternal protein deprivation or hypoxic stress can lead to significant increase in epinephrine and norepinephrine and can lead to permanent changes in cerebral blood flow and arterial contractility with associated obesity, hypertension, blood glucose dysregulation, fetal growth restriction and changes in DNA methylation (Goyal et al. 2009, 2010, 2011a,b, 2013, 2014, Ducsay et al. 2018). Moreover, reports demonstrate that increased cortisol and catecholamine secretion is also associated with gene expression changes in their receptors which are mediated by changes in DNA methylation (Jensen Pena et al. 2012). Furthermore, studies have demonstrated that paternal cold exposure can lead to differential DNA methylation of sperm and lead to protection from diet-induced obesity in the offspring (Sun et al. 2018). Similarly, maternal obesity has also been shown to modify DNA methylation and lead to increased adiposity in mice offspring (Borengasser et al. 2013). Of note, a recent study demonstrated that violence during pregnancy in human leads to changes in five CpG sites involved in circulatory system process (Serpeloni et al. 2017).
Another study in human placenta demonstrated three important clusters of DNA methylation regions related to metabolic pathways are altered in response to increased maternal stress (Brunst et al. 2018). Thus, it appears that maternal stress irrespective of type (caloric malnutrition, an imbalanced diet with low protein, hypothermia, hyperthermia, maternal overfeeding, as well as psychological stressors due to domestic violence) can lead to changes in DNA methylation and fetal programming to make the offspring more resilient to future stress. However, the nuances of changes in DNA methylation and transcriptional control of gene expression during $\mathrm{DOHaD}$ are not completely understood.

\section{Histone modifications and DOHaD}

DNA with accompanying histones is packaged in nucleosomes, the core of which contains an octamer of histone proteins. Five basic forms of histones (H1, H2A, $\mathrm{H} 2 \mathrm{~B}, \mathrm{H} 3$ and $\mathrm{H} 4$, as well as minor variants), are encircled by 146 base pairs of DNA (Smith et al. 1970, Luger et al. 1997). Histone modifications and DNA methylation confer a considerable increase in the information capacity of each nucleosome, allowing specific functions such as DNA repair and gene activation (Sarma \& Reinberg 2005). Enzymes associated with histone modifications are histone acetyltransferases (HAT), histone methyltransferases (HMT), histone deacetylases (HDAC), histone demethylases (HDM) and others (Klose et al. 2006, Dodd et al. 2007). These enzymes modify histones, which alter gene expression to affect the phenotype by regulating promoter activity, chromatin structure, dosage compensation and epigenetic memory, without changes in the nucleic acid code per se (Wolffe \& Matzke 1999, Martin \& Zhang 2005). These molecular alterations may be responsible for several disorders in the offspring during adult life.

Strahl and Allis proposed the histone code hypothesis, stating '... distinct histone modifications, on one or more tails, act sequentially or in combination to form a "histone code" that is read by other proteins to bring about distinct downstream events' (Strahl \& Allis 2000). Histone modifications change their interactions with DNA and shuttle the genes occupancy between heteroand euchromatin (Fig. 3). Gene expression is regulated by switching to a variant form of histone and by posttranslational modifications on histone tails (Bao \& Bedford 2016). It is well established that variant histones played an essential role in the evolution of complex life forms (Malik \& Henikoff 2003, Banaszynski et al. 2010). 
Thus, it is not surprising that modification to histones plays an important role in developmental programming. Studies have demonstrated that maternal and paternal stress induce histone modifications that affect phenotypes related to DOHaD (Zheng et al. 2011, Kilcoyne et al. 2014). Histone methylation of testicular germ cells during fetal life programs the generation of Leydig cells at puberty, which is responsible for testosterone secretion in adult men (Kilcoyne et al. 2014). Similarly, a high-starch diet in rats has been demonstrated to increased histone acetylation of genes associated with carbohydrate metabolism (Inoue et al. 2011) and may predispose adiposity. The chromatin (DNA and protein skeleton) of mature mammalian spermatozoa differs markedly in composition and structure from somatic chromatin. DNA is not associated with histones and arranged in nucleosomes. Instead, spermatozoa DNA is condensed with protamine, a highly basic protein possessing an arginine-rich central domain (Wouters-Tyrou et al. 1998). Following fertilization, the spermatozoa DNA is decondensed and remodeled into the transcriptionally competent chromatin of the male pronucleus. The chromatin is dispersed by removal of protamine, and the naked paternal DNA is acted upon by demethylase enzyme and undergoes active demethylation along with rewinding of the male DNA with maternal acetylated histones (Adenot et al. 1997). In contrast, oocyte DNA does not undergo any histone exchange or active demethylation. Of great importance, maternal protein deprivation reduces fetal amino acid availability, and this inactivates the mTOR signaling pathway, which is known to have significant histone deacetylase activity (Nishioka et al. 2008). Importantly, following fertilization, there are dynamic epigenetic changes in both paternal and maternal alleles in the zygote which are highly susceptible to maternal stressors. Balanced nutrient with adequate vitamins has been demonstrated to lower the thioredoxin-interacting protein expression, which has been proposed as a preimplantation stress marker and lead to better development of blastocysts by changing histone methylation (Ikeda et al. 2018). Moreover, studies have demonstrated that perinatal stressors such as protein deprivation can also alter histone acetylation (Sun et al. 2015). Similarly, high-fat diet is also known to alter histone acetylation as well as methylation which may lead to changes in gene expression in adipose tissue, liver, skeletal muscle and other fetal tissues (Masuyama \& Hiramatsu 2012, Suter et al. 2014, Bansal \& Simmons 2018). In contrast, a recent study showed that providing better environmental conditions during gestation reduced risk of Alzheimer's disease in the offspring by histone hyperacetylation (Liu et al. 2019). Additionally, studies demonstrate that extracellular histones secreted in the uterus may play a role in blastocyst implantation and increased nutrient supply to the growing embryo (Van Winkle \& Ryznar 2018). Furthermore, there is a cooperative mechanism between DNA methylation and histone acetylation, which leads to switching between hetero- and euchromatin (Mochizuki et al. 2017). It has been demonstrated that in FGR fetuses, the development of diabetes mellitus involves a reduction in pancreatic homeobox domain $1(\mathrm{pdx} 1)$, which is a result of cooperative regulation of gene expression by changes in histone acetylation, demethylation and DNA methylation (Park et al. 2008). Nonetheless, this is a much less studied mechanism as compared to DNA methylation and requires further investigation.

\section{miRNA and DOHaD}

Apart from DNA methylation and histone modifications, miRNAs have emerged as essential players in post-transcriptional gene regulation. These are subtypes of small, noncoding RNA, 21-25 nucleotides in length. miRNAs are capable of base pairing with mRNA, and fine-tuning gene expression during development and differentiation, by suppressing their expression in a sequence-specific manner. Following the discovery of first miRNA 'lin4' in 1993, as a small temporal RNA (Lee et al. 1993), there has been enormous growth in this family, and identification of their targets. Although miRNAs are similar to siRNA in their generation pathway and molecular characteristics, unlike siRNA, miRNA does not degrade the target mRNA. Instead, they target the 3' untranslated regions (UTR) of mRNAs with which they share partial sequence complementarily, thereby silencing post-transcriptional gene translation. In this way, the biological system increases or decreases miRNA production, which up or downregulate gene expression according to the biological need, thus producing desired morphologic and physiological response. miRNA can cross the placental barrier (Chang et al. 2017) and their regulation may occur in maternal, placental or fetal tissues to regulate the growth and development of the maternal-placental-fetal unit. Furthermore, placental miRNA (miR-141, miR-149, miR-229-5p and miR-135b) are secreted in maternal circulation and their concentrations decline after parturition (Chim et al. 2008). This indicates that placental-derived miRNAs in addition to regulating gene expression in the placenta are 
capable of regulating maternal conditions with obscure etiology, such as preeclampsia or related hypertensive disorders. Studies reveal differential expression of miRNA (miR-210 and miR-182) in placenta from patients with preeclampsia and with small for gestational age newborn infants (Pineles et al. 2007). A study also demonstrated that a very diverse and dynamic set of miRNA is expressed in the embryonic chick at 11 days of incubation (Hicks et al. 2008). Another valuable study in silkworm (Bombyx mori) demonstrated several stage-by-stage changes in expression of miRNA with specific time points during embryogenesis. For example, upregulation of miR-1 and bantam in late embryos, increased miR-34b expression was associated with stage transition between instar and molt larval stages, miR-274 expression was associated with silk gland growth and spinning activity and so forth. Studies from our laboratory demonstrate miR-27 involvement in the regulation of the renin-angiotensin pathway in lungs in response to maternal stressors such as hypoxia and protein deprivation (Goyal et al. 2011a, 2015). Moreover, with maternal hypoxia, we observed downregulation of miR-199b in placenta, which increases renin translation and downregulates miR-27a and miR-429. These miRNAs increase ACE1 and ACE2 protein concentrations in lungs (Goyal et al. 2010, 2011b). Studies from several other laboratories have also demonstrated that miRNAs are associated with developmental programming of various organs (Zucchi et al. 2013, Casas-Agustench et al. 2015). The organs and tissues investigated include heart (Yan \& Jiao 2016, Lock et al. 2017), brain (Petri et al. 2014) and several endocrine glands (pancreas, ovary, testes, hypothalamus and pituitary) (Kredo-Russo et al. 2012, Voglova et al. 2016). Of note, exposure to environmental toxins during human pregnancy affects miRNA expression in cord blood, which lead to increased disease susceptibility in offspring (Rager et al. 2014, Gillet et al. 2016). In the future, it will be important to study how maternal and placental stressors regulate particular miRNA expression to produce phenotypic alterations in the fetus.

\section{Long noncoding RNA and DOHaD}

Another important group of regulatory RNA is the lncRNA. These RNA molecules, unlike miRNA, can fold into a complex secondary and tertiary structure and serve as sponges for miRNA or provide a scaffold for proteins to form regulatory complexes (Fig. 3) (Rinn \& Chang 2012, Kumar $\&$ Goyal 2017). Recent studies have demonstrated that
lncRNAs regulate cellular differentiation and organismal development. For instance, lincRNA-RoR reprograms human-induced pluripotent stem cells (Loewer et al. 2010). The lincRNA ES1, ES2 and ES3 promote pluripotency and neuronal differentiation indicating a role in human brain development ( $\mathrm{Ng}$ et al. 2012) and linc-MD1 regulates muscle differentiation by acting as competing endogenous RNA in mouse and human myoblasts (Cesana et al. 2011). Linc-MD1 'sponges' miR-133 and miR-135 to regulate the expression of transcription factors MAML1 and MEF2C that activate muscle-specific gene expression (Cesana et al. 2011). Additionally, lncRNAs have been implicated in cardiovascular development (Kurian et al. 2015), and stem cell-based studies have highlighted the involvement of lncRNA Braveheart (AK143260; Bvht) in cardiac development (Klattenhoff et al. 2013). Kcnq1 was also reported to be involved in heart development during embryogenesis (Korostowski et al. 2012). Additionally, lncRNA Fendrr a lateral-mesoderm-specific lncRNA has been shown to modify chromatin, and thereby control the developmental signaling in the heart of genetically engineered mice (Grote et al. 2013). This study showed that Fendrr is an essential regulator of heart and body wall development. Furthermore, lncRNAs have been shown to affect adipogenesis and $\beta$-cell formation (Sun et al. 2013, Arnes et al. 2016, Singer \& Sussel 2018). Recent evidence indicates that lncRNAs are induced by hypoxia (Michalik et al. 2014), which provide new leads regarding their role in several physiological and pathological conditions where hypoxia is an associated factor. Growth arrestspecific transcript 5 (GAS5 lncRNA) is induced under conditions of nutrient deprivation (Kino et al. 2010). Thus, the current evidence supports important actions for IncRNA, which may only be in its infancy of scientific discovery but identifies new roles for noncoding genes to regulate the organism's development and function and potentially modify the developmental program in response fetal stressors. To decipher the lncRNA roles in $\mathrm{DOHaD}$, further work is needed.

\section{DOHaD and evidence from human studies}

Evidence from human studies that contributed toward the formulation of $\mathrm{DOHaD}$ hypothesis came from observations following the 'Hunger Winter' that occurred during World War II. This human tragedy provides useful lessons on the effects of caloric restriction/malnutrition because during this seven-month famine, the caloric ration fell to less than $25 \%$ of the recommended 
intake for adults. Although to an extent, children, pregnant and lactating women, received extra rations, they too suffered severe dietary restriction (Roseboom et al. 2001). Upon reaching adulthood, those infants who experienced nutritional scarcity showed a higher incidence of cardiovascular disease, type II diabetes (Roseboom et al. 2001, Kyle \& Pichard 2006) (Painter et al. 2005) and mood and personality disorders (Kim et al. 2015). Those fetuses exposed to maternal caloric restriction in mid-gestation had a much higher incidence of pulmonary disease, including bronchitis (Lopuhaa et al. 2000) and renal disease as evidenced by microalbuminuria (Painter et al. 2005). Females who were conceived during the famine also had a much higher prevalence of obesity as adults (Ravelli et al. 1999), and both males and females showed atherogenic lipid profiles (Roseboom et al. 2000). Concomitantly during WWII, the people of St. Petersburg and the surrounding area of Russia also were subjected to starvation due to the interdiction of food supplies by opposing forces. Although not as well documented as the Dutch experience, children born under these conditions were small for gestational age and developed health problems later in life (Neugebauer et al. 1999). Another example of the sequelae of antenatal food deprivation is that of the Biafran War in Nigeria (1967-1970) (Hult et al. 2010, Thurner et al. 2013). Again, records of these offspring are not as clear as those in Holland but reflect similar in utero transmission of metabolic diseases. Similarly, previous studies demonstrated that an increase in the incidence of diabetics in the population of the Pima Indians of Arizona was an evolutionary mechanism to survive chronic nutrient scarcity (Schulz \& Chaudhari 2015). Furthermore, diabetic mothers with macrosomic babies can program obesity in the offspring (Yajnik 2014).

Contemporary epidemiologic data on the role of maternal nutrition in determining the long-term health of offspring derives from the studies of Barker and colleagues in the United Kingdom (Barker 1992, 2002, 2003, 2008). Professor David JP Barker formally proposed the modern concept of the DOHaD, in the late-1980s, where through detailed historical records he associated cardiovascular disease with reduced fetal growth (Barker et al. 1989). In a related analysis, impaired glucose tolerance was shown to be strongly associated with reduced growth in early life due to beta-cell dysfunction (Hales et al. 1991). These authors also demonstrated the high correlation of cerebrovascular accidents in the 1970s, to increased neonatal mortality six decades earlier during the years 1911-1914 (Barker \& Osmond 1987). Besides, men born from 1911 to 1930, Barker and colleagues have shown an inverse correlation between the weights both at birth and at 1 year of age to coronary artery disease in adulthood (Barker et al. 1989, Barker 1993). A subsequent study disclosed a similar trend with birth weight among women, which illustrates both sexes are affected by developmental programming (Osmond et al. 1993).

Apart from the seminal studies on the Dutch Hunger Winter cohorts, there have been several human population studies which have reported that the nutritional state of individuals and other maternal stressors may have phenotypic consequences or their children and grandchildren (Lumley et al. 1985, Lumley \& Bakoula 1993, Kaati et al. 2002). An example of maternal nutrition-induced changes in progeny phenotype and underlying DNA methylation status is evident in patients with hyper-homocysteinemia (Ingrosso et al. 2003). This disorder is characterized by increased levels of cellular adenosylhomocysteine, a potent inhibitor of S-adenosylmethionine-dependent methyltransferases, and possibility altered DNA methylation. In these offspring with increased homocysteine concentrations, folate supplementation restored global methylation levels, as well as appropriate methylation of imprinted IGF2-H19 locus (Ingrosso et al. 2003). Accumulated evidence underscores the importance of folic acid, an important component of DNA methylation reaction, as a vital dietary factor in fetal development, and the manner in which it modulates disease risks later in life (Torrens et al. 2006). However, further investigations are needed to determine (as in the case of hyper-homocysteinemia) if altered DNA methylation plays a causative role in these phenotypic effects (McKay et al. 2004).

Nonetheless, an optimal uterine environment is central to the establishment of embryonic epigenetic patterns and fetal development (Vickaryous \& Whitelaw 2005). Because embryo culture and manipulation are used in the modern day assisted reproductive technologies (ARTs), the obvious concern is regarding the extent to which ART or related procedures affect DNA methylation patterns and other epigenetic modifications that lead to a higher risk of developing adult-onset diseases (Khosla et al. 2001, Vickaryous \& Whitelaw 2005, Feil 2006). An issue of great importance is the extent to which the chemical composition of culture medium, the duration of culture or other factors, play a role in affecting changes in DNA methylation or histone modifications which may play an essential role in DOHaD (Doherty et al. 2000, Khosla et al. 2001, Young et al. 2001, Mann et al. 2004).

Anadditionalconsiderationistheroleofenvironmental toxins in producing alterations in the nucleosome with 
epigenetic consequences. A notable example from the mid-twentieth century is the administration of the estrogen-receptor agonist diethylstilbestrol (DES) to women to reduce the risk of spontaneous abortion. Subsequent studies demonstrated that DES was associated with increased incidence of vaginal clear cell carcinoma (Swan 2000), and altered limb development in the first generation and deafness in the second generation (Stoll et al. 2003). Not only environmental compounds but drugs may also alter the expression of specific genes, as well as the stress-related chaperone heat shock protein (HSP)-90, which plays a role in histone modifications (Rutherford \& Lindquist 1998, Feil 2006).

In humans, many factors, genetic and epigenetic, can influence placental/fetal growth, development and longterm sequelae. Several hypotheses have been proposed to account for these phenomena. The initial thought was the environmental toxin/stressors lead to changes in genetic sequences (mutations), which may be the factor in the development of chronic disorders. Later on, single nucleotide polymorphism was a major area of investigation to understand the risk of these chronic disorders in adult life. However, the accumulating evidence indicates that epigenomic changes may be the primary factor in these disorders (Holness \& Sugden 2006).

\section{Summary}

Epigenetic modifications play an important role in normal cellular function, as well as the development and differentiation of various cell types (Monk et al. 1987, Reik et al. 2001, Drake \& Walker 2004, Rahnama et al. 2006). The epigenetic state can be disrupted by maternal environmental influences such as protein deprivation, caloric excess, hypoxia and so forth, which alter DNA methylation and modify histones. Also, a wide variety of environmental toxins, including low-dose radiation and psychological stress, have been demonstrated to be important in epigenetic mechanisms (Dolinoy 2007, Feinberg 2007, Jirtle \& Skinner 2007). Increasingly, epigenetic changes are being recognized to be of importance in aging and the development of cancer and other diseases (Gopalakrishnan et al. 2008, Goyal et al. 2013, 2015, Goyal \& Longo 2013). Despite the general understanding that DNA and/or histone modifications constitute a major mechanism in the pathogenesis of epigenesis, little is known of the molecular mechanisms whereby these chemical reactions/changes are regulated and/or how they are transmitted between generations
(Longo \& Goyal 2014, Longo et al. 2014, Ducsay et al. 2018). Nonetheless, the accumulating evidence suggests that the epigenetic basis of developmental origins of adult health and diseases is the primary factor in metabolic syndrome (hypertension, obesity and diabetes mellitus). A future challenge is to develop strategies to negate the long-term consequences of these molecular alterations.

\section{Declaration of interest}

Sean Limesand is a Senior Editor of Journal of Endocrinology. Sean Limesand was not involved in the review or editorial process for this paper, on which he is listed as an author. The other authors have nothing to disclose.

\section{Funding}

This work did not receive any specific grant from any funding agency in the public, commercial or not-for-profit sector.

\section{References}

Abdalla H, Yoshizawa Y \& Hochi S 2009 Active demethylation of paternal genome in mammalian zygotes. Journal of Reproduction and Development 55 356-360. (https://doi.org/10.1262/jrd.20234)

Adenot PG, Mercier Y, Renard JP \& Thompson EM 1997 Differential $\mathrm{H} 4$ acetylation of paternal and maternal chromatin precedes DNA replication and differential transcriptional activity in pronuclei of 1-cell mouse embryos. Development 124 4615-4625.

Agarwal P, Morriseau TS, Kereliuk SM, Doucette CA, Wicklow BA \& Dolinsky VW 2018 Maternal obesity, diabetes during pregnancy and epigenetic mechanisms that influence the developmental origins of cardiometabolic disease in the offspring. Critical Reviews in Clinical Laboratory Sciences 55 71-101. (https://doi.org/10.1080/10408363.20 17.1422109)

Arnes L, Akerman I, Balderes DA, Ferrer J \& Sussel L 2016 betalinc1 encodes a long noncoding RNA that regulates islet beta-cell formation and function. Genes and Development 30 502-507. (https://doi. org/10.1101/gad.273821.115)

Banaszynski LA, Allis CD \& Lewis PW 2010 Histone variants in metazoan development. Developmental Cell 19 662-674. (https://doi. org/10.1016/j.devcel.2010.10.014)

Bansal A \& Simmons RA 2018 Epigenetics and developmental origins of diabetes: correlation or causation? American Journal of Physiology: Endocrinology and Metabolism 315 E15-E28. (https://doi.org/10.1152/ ajpendo.00424.2017)

Bao J \& Bedford MT 2016 Epigenetic regulation of the histone-toprotamine transition during spermiogenesis. Reproduction $\mathbf{1 5 1}$ R55-R70. (https://doi.org/10.1530/REP-15-0562)

Barker DJ 1992 Fetal growth and adult disease. British Journal of Obstetrics and Gynaecology 99 275-276. (https://doi. org/10.1111/j.1471-0528.1992.tb13719.x)

Barker DJP 1993 Maternal nutrition and cardiovascular disease. Nutrition and Health 9 99-106. (https://doi.org/10.1177/026010609300900206)

Barker DJ 2002 Fetal programming of coronary heart disease. Trends in Endocrinology and Metabolism 13 364-368. (https://doi.org/10.1016/ S1043-2760(02)00689-6)

Barker DJ 2003 The developmental origins of adult disease. European Journal of Epidemiology 18 733-736.

Barker DJ 2008 Human growth and cardiovascular disease. Nestlé Nutrition Workshop Series: Pediatric Program 61 21-38. (https://doi. org/10.1159/000113163)
(C) 2019 Society for Endocrinology Published by Bioscientifica Ltd. Printed in Great Britain 
Barker DJ \& Osmond C 1987 Death rates from stroke in England and Wales predicted from past maternal mortality. BMJ 295 83-86. (https://doi.org/10.1136/bmj.295.6590.83)

Barker DJ, Osmond C, Golding J, Kuh D \& Wadsworth ME 1989 Growth in utero, blood pressure in childhood and adult life, and mortality from cardiovascular disease. BMJ 298 564-567. (https://doi. org/10.1136/bmj.298.6673.564)

Barker DJ, Osmond C, Forsen TJ, Kajantie E \& Eriksson JG 2007 Maternal and social origins of hypertension. Hypertension $\mathbf{5 0} 565-571$. (https:// doi.org/10.1161/HYPERTENSIONAHA.107.091512)

Bestor TH 2000 The DNA methyltransferases of mammals. Human Molecular Genetics 9 2395-2402. (https://doi.org/10.1093/hmg/9.16.2395)

Boehmer BH, Limesand SW \& Rozance PJ 2017 The impact of IUGR on pancreatic islet development and beta-cell function. Journal of Endocrinology 235 R63-R76. (https://doi.org/10.1530/JOE-17-0076)

Bogdarina I, Welham S, King PJ, Burns SP \& Clark AJL 2007 Epigenetic modification of the renin-angiotensin system in the fetal programming of hypertension. Circulation Research 100 520-526. (https://doi.org/10.1161/01.RES.0000258855.60637.58)

Borengasser SJ, Zhong Y, Kang P, Lindsey F, Ronis MJ, Badger TM, Gomez-Acevedo H \& Shankar K 2013 Maternal obesity enhances white adipose tissue differentiation and alters genome-scale DNA methylation in male rat offspring. Endocrinology 154 4113-4125. (https://doi.org/10.1210/en.2012-2255)

Brawley L, Itoh S, Torrens C, Barker A, Bertram C, Poston L \& Hanson M 2003 Dietary protein restriction in pregnancy induces hypertension and vascular defects in rat male offspring. Pediatric Research 54 83-90. (https://doi.org/10.1203/01.PDR.0000065731.00639.02)

Brunst KJ, Tignor N, Just A, Liu Z, Lin X, Hacker MR, Bosquet Enlow M, Wright RO, Wang P, Baccarelli AA, et al. 2018 Cumulative lifetime maternal stress and epigenome-wide placental DNA methylation in the PRISM cohort. Epigenetics 13 665-681. (https://doi.org/10.1080/15 592294.2018.1497387)

Casas-Agustench P, Iglesias-Gutierrez E \& Davalos A 2015 Mother's nutritional miRNA legacy: nutrition during pregnancy and its possible implications to develop cardiometabolic disease in later life. Pharmacological Research 100 322-334. (https://doi.org/10.1016/j. phrs.2015.08.017)

Cesana M, Cacchiarelli D, Legnini I, Santini T, Sthandier O, Chinappi M, Tramontano A \& Bozzoni I 2011 A long noncoding RNA controls muscle differentiation by functioning as a competing endogenous RNA. Cell 147 358-369. (https://doi.org/10.1016/j.cell.2011.09.028)

Chang G, Mouillet JF, Mishima T, Chu T, Sadovsky E, Coyne CB, Parks WT, Surti U \& Sadovsky Y 2017 Expression and trafficking of placental microRNAs at the feto-maternal interface. FASEB Journal 31 2760-2770. (https://doi.org/10.1096/fj.201601146R)

Chim SSC, Shing TKF, Hung ECW, Leung T-y, Lau T-k, Chiu RWK \& Lo YM 2008 Detection and characterization of placental microRNAs in maternal plasma. Clinical Chemistry 54 482-490. (https://doi. org/10.1373/clinchem.2007.097972)

Dawlaty MM, Ganz K, Powell BE, Hu YC, Markoulaki S, Cheng AW, Gao Q, Kim J, Choi SW, Page DC, et al. 2011 Tet1 is dispensable for maintaining pluripotency and its loss is compatible with embryonic and postnatal development. Cell Stem Cell 9 166-175. (https://doi. org/10.1016/j.stem.2011.07.010)

Dawlaty MM, Breiling A, Le T, Raddatz G, Barrasa MI, Cheng AW, Gao Q, Powell BE, Li Z, Xu M, et al. 2013 Combined deficiency of Tet1 and Tet 2 causes epigenetic abnormalities but is compatible with postnatal development. Developmental Cell 24 310-323. (https://doi. org/10.1016/j.devcel.2012.12.015)

Dawlaty MM, Breiling A, Le T, Barrasa MI, Raddatz G, Gao Q, Powell BE, Cheng AW, Faull KF, Lyko F, et al. 2014 Loss of Tet enzymes compromises proper differentiation of embryonic stem cells. Developmental Cell 29 102-111. (https://doi.org/10.1016/j. devcel.2014.03.003)
Dodd IB, Micheelsen MA, Sneppen K \& Thon G 2007 Theoretical analysis of epigenetic cell memory by nucleosome modification. Cell 129 813-822. (https://doi.org/10.1016/j.cell.2007.02.053)

Doherty AS, Mann MR, Tremblay KD, Bartolomei MS \& Schultz RM 2000 Differential effects of culture on imprinted H19 expression in the preimplantation mouse embryo. Biology of Reproduction $\mathbf{6 2}$ 1526-1535. (https://doi.org/10.1095/biolreprod62.6.1526)

Dolinoy DC 2007 Epigenetic gene regulation: early environmental exposures. Pharmacogenomics 8 5-10. (https://doi. org/10.2217/14622416.8.1.5)

Drake AJ \& Walker BR 2004 The intergenerational effects of fetal programming: non-genomic mechanisms for the inheritance of low birth weight and cardiovascular risk. Journal of Endocrinology 180 1-16. (https://doi.org/10.1677/joe.0.1800001)

Ducsay CA, Goyal R, Pearce WJ, Wilson S, Hu XQ \& Zhang L 2018 Gestational hypoxia and developmental plasticity. Physiological Reviews 98 1241-1334. (https://doi.org/10.1152/ physrev.00043.2017)

Evain-Brion D \& Malassine A 2003 Human placenta as an endocrine organ. Growth Hormone and IGF Research 13 (Supplement A) S34-S37. (https://doi.org/10.1016/S1096-6374(03)00053-4)

Feil R 2006 Environmental and nutritional effects on the epigenetic regulation of genes. Mutation Research/Fundamental and Molecular Mechanisms of Mutagenesis 600 46-57. (https://doi.org/10.1016/j. mrfmmm.2006.05.029)

Feinberg AP 2007 Phenotypic plasticity and the epigenetics of human disease. Nature 447 433-440. (https://doi.org/10.1038/nature05919)

Gillet V, Hunting DJ \& Takser L 2016 Turing revisited: decoding the microRNA messages in brain extracellular vesicles for early detection of neurodevelopmental disorders. Current Environmental Health Reports 3 188-201. (https://doi.org/10.1007/s40572-016-0093-0)

Gluckman PD, Beedle AS, Hanson MA \& Yap EP 2008 Developmental perspectives on individual variation: implications for understanding nutritional needs. Nestlé Nutrition Institute Workshop Series: Pediatric Program 62 1-12. (https://doi.org/10.1159/000146243)

Gopalakrishnan S, Van Emburgh BO \& Robertson KD 2008 DNA methylation in development and human disease. Mutation Research/ Fundamental and Molecular Mechanisms of Mutagenesis 647 30-38. (https://doi.org/10.1016/j.mrfmmm.2008.08.006)

Goyal R \& Longo LD 2013 Maternal protein deprivation: sexually dimorphic programming of hypertension in the mouse. Hypertension Research 36 29-35. (https://doi.org/10.1038/hr.2012.129)

Goyal R, Galffy A, Field SA, Gheorghe CP, Mittal A \& Longo LD 2009 Maternal protein deprivation: changes in systemic renin-angiotensin system of the mouse fetus. Reproductive Sciences 16 894-904. (https:// doi.org/10.1177/1933719109337260)

Goyal R, Goyal D, Leitzke A, Gheorghe CP \& Longo LD 2010 Brain renin-angiotensin system: fetal epigenetic programming by maternal protein restriction during pregnancy. Reproductive Sciences $\mathbf{1 7}$ 227-238. (https://doi.org/10.1177/1933719109351935)

Goyal R, Leitzke A, Goyal D, Gheorghe CP \& Longo LD 2011a Antenatal maternal hypoxic stress. Reproductive Sciences 18 180-189. (https:// doi.org/10.1177/1933719110385134)

Goyal R, Lister R, Leitzke A, Goyal D, Gheorghe CP \& Longo LD $2011 b$ Antenatal maternal hypoxic stress: adaptations of the placental reninangiotensin system in the mouse. Placenta 32 134-139. (https://doi. org/10.1016/j.placenta.2010.11.004)

Goyal R, Wong C, Van Wickle J \& Longo L 2013 Antenatal maternal protein deprivation: sexually dimorphic programming of the pancreatic renin-angiotensin system. Journal of the Renin-AngiotensinAldosterone System 14 137-145.

Goyal R, Goyal D, Chu N, Van Wickle J \& Longo LD 2014 Cerebral artery Alpha-1 AR subtypes: high altitude long-term acclimatization responses. PLOS ONE 9 e112784. (https://doi.org/10.1371/journal. pone.0112784) https://joe.bioscientifica.com

https://doi.org/10.1530/JOE-19-0009 (c) 2019 Society for Endocrinology Published by Bioscientifica Ltd. Printed in Great Britain 
Goyal R, Van-Wickle J, Goyal D \& Longo LD 2015 Antenatal maternal low protein diet: ACE-2 in the mouse lung and sexually dimorphic programming of hypertension. BMC Physiology 15 2. (https://doi. org/10.1186/s12899-015-0016-6)

Grote P, Wittler L, Hendrix D, Koch F, Währisch S, Beisaw A, Macura K, Bläss G, Kellis M, Werber M, et al. 2013 The tissue-specific lncRNA Fendrr is an essential regulator of heart and body wall development in the mouse. Developmental Cell 24 206-214.

Guo JU, Su Y, Zhong C, Ming G-L \& Song H 2011 Hydroxylation of 5-methylcytosine by TET1 promotes active DNA demethylation in the adult brain. Cell 145 423-434. (https://doi.org/10.1016/j. cell.2011.03.022)

Hales CN, Barker DJ, Clark PM, Cox LJ, Fall C, Osmond C \& Winter PD 1991 Fetal and infant growth and impaired glucose tolerance at age 64. BMJ 303 1019-1022.

Hanson MA \& Gluckman PD 2008 Developmental origins of health and disease: new insights. Basic and Clinical Pharmacology and Toxicology 102 90-93. (https://doi.org/10.1111/j.1742-7843.2007.00186.x)

Hicks JA, Tembhurne P \& Liu H-C 2008 MicroRNA expression in chicken embryos. Poultry Science 87 2335-2343. (https://doi.org/10.3382/ ps.2008-00114)

Hoek HW, Susser E, Buck KA, Lumey LH, Lin SP \& Gorman JM 1996 Schizoid personality disorder after prenatal exposure to famine. American Journal of Psychiatry 153 1637-1639.

Holness MJ \& Sugden MC 2006 Epigenetic regulation of metabolism in children born small for gestational age. Current Opinion in Clinical Nutrition and Metabolic Care 9 482-488. (https://doi.org/10.1097/01. mco.0000232912.69236.e0)

Hu XQ, Chen M, Dasgupta C, Xiao D, Huang X, Yang S \& Zhang L 2017 Chronic hypoxia upregulates DNA methyltransferase and represses large conductance $\mathrm{Ca} 2+$-activated $\mathrm{K}+$ channel function in ovine uterine arteriesdagger. Biology of Reproduction 96 424-434. (https://doi. org/10.1095/biolreprod.116.145946)

Hult M, Tornhammar P, Ueda P, Chima C, Bonamy AK, Ozumba B \& Norman M 2010 Hypertension, diabetes and overweight: looming legacies of the Biafran famine. PLOS ONE 5 e13582. (https://doi. org/10.1371/journal.pone.0013582)

Ikeda S, Sugimoto M \& Kume S 2018 The RPMI-1640 vitamin mixture promotes bovine blastocyst development in vitro and downregulates gene expression of TXNIP with epigenetic modification of associated histones. Journal of Developmental Origins of Health and Disease 9 87-94. (https://doi.org/10.1017/S2040174417000563)

Ingrosso D, Cimmino A, Perna AF, Masella L, De Santo NG, De Bonis ML Vacca M, D'Esposito M, D’Urso M, Galletti P, et al. 2003 Folate treatment and unbalanced methylation and changes of allelic expression induced by hyperhomocysteinaemia in patients with uraemia. Lancet 361 1693-1699. (https://doi.org/10.1016/S01406736(03)13372-7)

Inoue S, Mochizuki K \& Goda T 2011 Jejunal induction of SI and SGLT1 genes in rats by high-starch/low-fat diet is associated with histone acetylation and binding of GCN5 on the genes. Journal of Nutritional Science and Vitaminology 57 162-169. (https://doi.org/10.3177/ jnsv.57.162)

Ito S, D'Alessio AC, Taranova OV, Hong K, Sowers LC \& Zhang Y 2010 Role of Tet proteins in $5 \mathrm{mC}$ to $5 \mathrm{hmC}$ conversion, ES-cell self-renewal and inner cell mass specification. Nature 466 1129-1133. (https://doi. org/10.1038/nature09303)

Jang EA, Longo LD \& Goyal R 2015 Antenatal maternal hypoxia: criterion for fetal growth restriction in rodents. Frontiers in Physiology 6176. (https://doi.org/10.3389/fphys.2015.00176)

Jansson T \& Powell TL 2007 Role of the placenta in fetal programming: underlying mechanisms and potential interventional approaches. Clinical Science 113 1-13. (https://doi.org/10.1042/CS20060339)

Jeltsch A, Ehrenhofer-Murray A, Jurkowski TP, Lyko F, Reuter G, Ankri S, Nellen W, Schaefer M \& Helm M 2017 Mechanism and biological role of Dnmt2 in nucleic acid methylation. RNA Biology 14 1108-1123. (https://doi.org/10.1080/15476286.2016.1191737)

Jensen Pena C, Monk C \& Champagne FA 2012 Epigenetic effects of prenatal stress on 11beta-hydroxysteroid dehydrogenase- 2 in the placenta and fetal brain. PLOS ONE 7 e39791. (https://doi. org/10.1371/journal.pone.0039791)

Jirtle RL \& Skinner MK 2007 Environmental epigenomics and disease susceptibility. Nature Reviews: Genetics 8 253-262. (https://doi. org/10.1038/nrg2045)

Kaati G, Bygren LO \& Edvinsson S 2002 Cardiovascular and diabetes mortality determined by nutrition during parents' and grandparents' slow growth period. European Journal of Human Genetics 10 682-688. (https://doi.org/10.1038/sj.ejhg.5200859)

Kafri T, Ariel M, Brandeis M, Shemer R, Urven L, McCarrey J, Cedar H \& Razin A 1992 Developmental pattern of gene-specific DNA methylation in the mouse embryo and germ line. Genes and Development 6 705-714.

Khosla S, Dean W, Reik W \& Feil R 2001 Culture of preimplantation embryos and its long-term effects on gene expression and phenotype. Human Reproduction Update 7 419-427. (https://doi.org/10.1093/ humupd/7.4.419)

Kilcoyne KR, Smith LB, Atanassova N, Macpherson S, Mckinnell C, Van Den Driesche S, Jobling MS, Chambers TJ, De Gendt K, Verhoeven G, et al. 2014 Fetal programming of adult Leydig cell function by androgenic effects on stem/progenitor cells. PNAS 111 E1924-E1932. (https://doi.org/10.1073/pnas.1320735111)

Kim DR, Bale TL \& Epperson CN 2015 Prenatal programming of mental illness: current understanding of relationship and mechanisms. Current Psychiatry Reports 17 5. (https://doi.org/10.1007/s11920-0140546-9)

Kino T, Hurt DE, Ichijo T, Nader N \& Chrousos GP 2010 Noncoding RNA gas5 is a growth arrest- and starvation-associated repressor of the glucocorticoid receptor. Science Signaling 3 ra8. (https://doi. org/10.1126/scisignal.2000568)

Klattenhoff C, Scheuermann J, Surface L, Bradley R, Fields P, Steinhauser M, Ding H, Butty V, Torrey L, Haas S, et al. 2013 Braveheart, a long noncoding RNA required for cardiovascular lineage commitment. Cell 152 570-583. (https://doi.org/10.1016/j.cell.2013.01.003)

Klose RJ, Kallin EM \& Zhang Y 2006 JmjC-domain-containing proteins and histone demethylation. Nature Reviews: Genetics 7 715-727. (https://doi.org/10.1038/nrg1945)

Korostowski L, Sedlak N \& Engel N 2012 The Kcnq1ot1 long non-coding RNA affects chromatin conformation and expression of Kcnq1, but does not regulate its imprinting in the developing heart. PLoS Genetics 8 e1002956.

Kredo-Russo S, Mandelbaum AD, Ness A, Alon I, Lennox KA, Behlke MA \& Hornstein E 2012 Pancreas-enriched miRNA refines endocrine cell differentiation. Development 139 3021-3031. (https://doi.org/10.1242/ dev.080127)

Kumar MM \& Goyal R 2017 LncRNA as a therapeutic target for angiogenesis. Current Topics in Medicinal Chemistry 17 1750-1757. (https://doi.org/10.2174/1568026617666161116144744)

Kurian L, Aguirre A, Sancho-Martinez I, Benner C, Hishida T, Nguyen TB, Reddy P, Nivet E, Krause MN, Nelles DA, et al. 2015 Identification of novel long noncoding RNAs underlying vertebrate cardiovascular development. Circulation 131 1278-1290. (https://doi.org/10.1161/ CIRCULATIONAHA.114.013303)

Kwong WY, Wild AE, Roberts P, Willis AC \& Fleming TP 2000 Maternal undernutrition during the preimplantation period of rat development causes blastocyst abnormalities and programming of postnatal hypertension. Development 127 4195-4202.

Kyle UG \& Pichard C 2006 The Dutch Famine of 1944-1945: a pathophysiological model of long-term consequences of wasting disease. Current Opinion in Clinical Nutrition and Metabolic Care 9 388-394. (https://doi.org/10.1097/01.mco.0000232898.74415.42) https://joe.bioscientifica.com

https://doi.org/10.1530/JOE-19-0009 (c) 2019 Society for Endocrinology Published by Bioscientifica Ltd. Printed in Great Britain 
Lecoutre S, Pourpe C, Butruille L, Marousez L, Laborie C, Guinez C, Lesage J, Vieau D, Eeckhoute J, Gabory A, et al. 2018 Reduced PPARgamma2 expression in adipose tissue of male rat offspring from obese dams is associated with epigenetic modifications. FASEB Journal 32 2768-2778. (https://doi.org/10.1096/fj.201700997R)

Lee RC, Feinbaum RL \& Ambros V 1993 The C. elegans heterochronic gene lin-4 encodes small RNAs with antisense complementarity to lin-14. Cell $\mathbf{7 5}$ 843-854.

Leonhardt H \& Bestor TH 1993 Structure, function and regulation of mammalian DNA methyltransferase. EXS 64 109-119.

Li E, Bestor TH \& Jaenisch R 1992 Targeted mutation of the DNA methyltransferase gene results in embryonic lethality. Cell 69 915-926.

Limesand SW, Rozance PJ, Zerbe GO, Hutton JC \& Hay WW 2006 Attenuated insulin release and storage in fetal sheep pancreatic islets with intrauterine growth restriction. Endocrinology 147 1488-1497. (https://doi.org/10.1210/en.2005-0900)

Liu E, Zhou Q, Xie AJ, Li M, Zhang S, Huang H, Liuyang Z, Wang Y, Liu B, Li X, et al. 2019 Enriched gestation activates the IGF pathway to evoke embryo-adult benefits to prevent Alzheimer's disease. Translational Neurodegeneration 8 8. (https://doi.org/10.1186/s40035019-0149-9)

Lock MC, Botting KJ, Tellam RL, Brooks D \& Morrison JL 2017 Adverse intrauterine environment and cardiac miRNA expression. International Journal of Molecular Sciences 18. (https://doi.org/10.3390/ ijms18122628)

Loewer S, Cabili MN, Guttman M, Loh YH, Thomas K, Park IH, Garber M, Curran M, Onder T, Agarwal S, et al. 2010 Large intergenic noncoding RNA-RoR modulates reprogramming of human induced pluripotent stem cells. Nature Genetics 42 1113-1117. (https://doi. org/10.1038/ng.710)

Longo LD \& Goyal R 2014 Maternal stress-mediated gene expression changes in the mouse placenta: a mosaic hypothesis of epigenesis. In The Guide to Investigation of Mouse Pregnancy, 1st ed. Eds BA Croy, AT Yamada, FJ Demayo \& SL Adamson. Cambridge, MA, USA: Academic Press.

Longo LD, Zhang L \& Goyal R 2014 The developing brain: what is the role of antenatal stress-mediated epigenetics? In Stress and Developmental Programming of Health and Disease: Beyond Phenomenology. Eds L Zhang \& L Longo. New York, NY, USA: Nova Science Publishers Inc.

Lopuhaa CE, Roseboom TJ, Osmond C, Barker DJ, Ravelli AC, Bleker OP, Van Der Zee JS \& Van Der Meulen JH 2000 Atopy, lung function, and obstructive airways disease after prenatal exposure to famine. Thorax 55 555-561. (https://doi.org/10.1136/thorax.55.7.555)

Luger K, Mader AW, Richmond RK, Sargent DF \& Richmond TJ 1997 Crystal structure of the nucleosome core particle at 2.8 A resolution. Nature 389 251-260. (https://doi.org/10.1038/38444)

Lumley J \& Bakoula C 1993 Perinatal mortality in Greece and Greekborn women in Victoria. What does a 'natural experiment' suggest? European Journal of Obstetrics, Gynecology, and Reproductive Biology 50 65-70.

Lumley J, Correy JF, Newman NM \& Curran JT 1985 Low birth weight in Tasmania 1975-1983: the effect of socioeconomic status. Australian Paediatric Journal 21 13-14. (https://doi. org/10.1111/j.1440-1754.1985.tb00116.x)

Malik HS \& Henikoff S 2003 Phylogenomics of the nucleosome. Nature Structural Biology 10 882-891. (https://doi.org/10.1038/nsb996)

Mann MR, Lee SS, Doherty AS, Verona RI, Nolen LD, Schultz RM \& Bartolomei MS 2004 Selective loss of imprinting in the placenta following preimplantation development in culture. Development 131 3727-3735. (https://doi.org/10.1242/dev.01241)

Martin C \& Zhang Y 2005 The diverse functions of histone lysine methylation. Nature Reviews: Molecular Cell Biology 6 838-849. (https://doi.org/10.1038/nrm1761)
Masuyama H \& Hiramatsu Y 2012 Effects of a high-fat diet exposure in utero on the metabolic syndrome-like phenomenon in mouse offspring through epigenetic changes in adipocytokine gene expression. Endocrinology 153 2823-2830. (https://doi.org/10.1210/ en.2011-2161)

Mayer W, Niveleau A, Walter J, Fundele R \& Haaf T 2000 Demethylation of the zygotic paternal genome. Nature 403 501-502. (https://doi. org/10.1038/35000654)

McKay JA, Williams EA \& Mathers JC 2004 Folate and DNA methylation during in utero development and aging. Biochemical Society Transactions 32 1006-1007. (https://doi.org/10.1042/BST0321006)

Meehan RR 2003 DNA methylation in animal development. Seminars in Cell and Developmental Biology 14 53-65.

Michalik KM, You X, Manavski Y, Doddaballapur A, Zörnig M, Braun T, John D, Ponomareva Y, Chen W, Uchida S, et al. 2014 Long noncoding RNA MALAT1 regulates endothelial cell function and vessel growth. Circulation Research 114 1389-1397. (https://doi. org/10.1161/CIRCRESAHA.114.303265)

Mochizuki K, Hariya N, Honma K \& Goda T 2017 Relationship between epigenetic regulation, dietary habits, and the developmental origins of health and disease theory. Congenital Anomalies 57 184-190. (https://doi.org/10.1111/cga.12213)

Mohr F, Döhner K, Buske C \& Rawat VP 2011 TET genes: new players in DNA demethylation and important determinants for stemness. Experimental Hematology 39 272-281. (https://doi.org/10.1016/j. exphem.2010.12.004)

Monk M, Boubelik M \& Lehnert S 1987 Temporal and regional changes in DNA methylation in the embryonic, extraembryonic and germ cell lineages during mouse embryo development. Development 99 371-382.

Neugebauer R, Hoek HW \& Susser E 1999 Prenatal exposure to wartime famine and development of antisocial personality disorder in early adulthood. JAMA 282 455-462. (https://doi.org/10.1001/ jama.282.5.455)

Ng SY, Johnson R \& Stanton LW 2012 Human long non-coding RNAs promote pluripotency and neuronal differentiation by association with chromatin modifiers and transcription factors. EMBO Journal $\mathbf{3 1}$ 522-533. (https://doi.org/10.1038/emboj.2011.459)

Nishioka C, Ikezoe T, Yang J, Koeffler HP \& Yokoyama A 2008 Blockade of mTOR signaling potentiates the ability of histone deacetylase inhibitor to induce growth arrest and differentiation of acute myelogenous leukemia cells. Leukemia 22 2159-2168. (https://doi. org/10.1038/leu.2008.243)

Obeid R, Schadt A, Dillmann U, Kostopoulos P, Fassbender K \& Herrmann W 2009 Methylation status and neurodegenerative markers in Parkinson disease. Clinical Chemistry 55 1852-1860. (https://doi.org/10.1373/clinchem.2009.125021)

Okano M, Bell DW, Haber DA \& Li E 1999 DNA methyltransferases Dnmt3a and Dnmt3b are essential for de novo methylation and mammalian development. Cell 99 247-257. (https://doi.org/10.1016/ S0092-8674(00)81656-6)

Osmond C, Barker DJ, Winter PD, Fall CH \& Simmonds SJ 1993 Early growth and death from cardiovascular disease in women. BMJ $\mathbf{3 0 7}$ 1519-1524.

Oswald J, Engemann S, Lane N, Mayer W, Olek A, Fundele R, Dean W, Reik W \& Walter J 2000 Active demethylation of the paternal genome in the mouse zygote. Current Biology $10475-478$.

Painter RC, Roseboom TJ, Van Montfrans GA, Bossuyt PM, Krediet RT, Osmond C, Barker DJ \& Bleker OP 2005 Microalbuminuria in adults after prenatal exposure to the Dutch famine. Journal of the American Society of Nephrology 16 189-194. (https://doi.org/10.1681/ ASN.2004060474)

Park JH, Stoffers DA, Nicholls RD \& Simmons RA 2008 Development of type 2 diabetes following intrauterine growth retardation in rats is associated with progressive epigenetic silencing of Pdx1. Journal https://joe.bioscientifica.com

https://doi.org/10.1530/JOE-19-0009 (c) 2019 Society for Endocrinology Published by Bioscientifica Ltd. Printed in Great Britain 
of Clinical Investigation 118 2316-2324. (https://doi.org/10.1172/ JCI33655)

Petri R, Malmevik J, Fasching L, Akerblom M \& Jakobsson J 2014 miRNAs in brain development. Experimental Cell Research 321 84-89. (https:// doi.org/10.1016/j.yexcr.2013.09.022)

Pineles BL, Romero R, Montenegro D, Tarca AL, Han YM, Kim YM, Draghici S, Espinoza J, Kusanovic JP, Mittal P, et al. 2007 Distinct subsets of microRNAs are expressed differentially in the human placentas of patients with preeclampsia. American Journal of Obstetrics and Gynecology 196 261.e1-261.e6. (https://doi.org/10.1016/j.ajog.2007.01.008)

Poh WJ, Wee CP \& Gao Z 2016 DNA methyltransferase activity assays: advances and challenges. Theranostics 6 369-391. (https://doi. org/10.7150/thno.13438)

Pradhan S \& Esteve PO 2003 Mammalian DNA (cytosine-5) methyltransferases and their expression. Clinical Immunology 109 6-16.

Rager JE, Bailey KA, Smeester L, Miller SK, Parker JS, Laine JE, Drobna Z, Currier J, Douillet C, Olshan AF, et al. 2014 Prenatal arsenic exposure and the epigenome: altered microRNAs associated with innate and adaptive immune signaling in newborn cord blood. Environmental and Molecular Mutagenesis 55 196-208. (https://doi.org/10.1002/em.21842)

Rahnama F, Shafiei F, Gluckman PD, Mitchell MD \& Lobie PE 2006 Epigenetic regulation of human trophoblastic cell migration and invasion. Endocrinology 147 5275-5283. (https://doi.org/10.1210/ en.2006-0288)

Ravelli AC, van Der Meulen JH, Osmond C, Barker DJ \& Bleker OP 1999 Obesity at the age of $50 \mathrm{y}$ in men and women exposed to famine prenatally. American Journal of Clinical Nutrition 70 811-816. (https:// doi.org/10.1093/ajcn/70.5.811)

Reik W, Dean W \& Walter J 2001 Epigenetic reprogramming in mammalian development. Science 293 1089-1093. (https://doi. org/10.1126/science.1063443)

Rinn JL \& Chang HY 2012 Genome regulation by long noncoding RNAs. Annual Review of Biochemistry 81 145-166. (https://doi.org/10.1146/ annurev-biochem-051410-092902)

Roseboom TJ, Van Der Meulen JH, Osmond C, Barker DJ, Ravelli AC \& Bleker OP 2000 Plasma lipid profiles in adults after prenatal exposure to the Dutch famine. American Journal of Clinical Nutrition 72 1101-1106. (https://doi.org/10.1093/ajcn/72.5.1101)

Roseboom TJ, Van Der Meulen JH, Ravelli AC, Osmond C, Barker DJ \& Bleker OP 2001 Effects of prenatal exposure to the Dutch famine on adult disease in later life: an overview. Molecular and Cellular Endocrinology 185 93-98. (https://doi.org/10.1016/S03037207(01)00721-3)

Rutherford SL \& Lindquist S 1998 Hsp90 as a capacitor for morphological evolution. Nature 396 336-342. (https://doi. org/10.1038/24550)

Sarma K \& Reinberg D 2005 Histone variants meet their match. Nature Reviews: Molecular Cell Biology 6 139-149. (https://doi.org/10.1038/ nrm1567)

Schaefer M \& Lyko F 2009 Solving the Dnmt2 enigma. Chromosoma 119 35-40. (https://doi.org/10.1007/s00412-009-0240-6)

Schmutte C \& Jones PA 1998 Involvement of DNA methylation in human carcinogenesis. Biological Chemistry 379 377-388.

Schulz LO \& Chaudhari LS 2015 High-risk populations: the pimas of Arizona and Mexico. Current Obesity Reports 4 92-98. (https://doi. org/10.1007/s13679-014-0132-9)

Serpeloni F, Radtke K, De Assis SG, Henning F, Natt D \& Elbert T 2017 Grandmaternal stress during pregnancy and DNA methylation of the third generation: an epigenome-wide association study. Translational Psychiatry 7 e1202. (https://doi.org/10.1038/tp.2017.153)

Singer RA \& Sussel L 2018 Islet long noncoding RNAs: a playbook for discovery and characterization. Diabetes 67 1461-1470. (https://doi. org/10.2337/dbi18-0001)

Smith EL, Delange RJ \& Bonner J 1970 Chemistry and biology of the histones. Physiological Reviews 50 159-170. (https://doi.org/10.1152/ physrev.1970.50.2.159)
Solano ME, Kowal MK, O'Rourke GE, Horst AK, Modest K, Plosch T, Barikbin R, Remus CC, Berger RG, Jago C, et al. 2015 Progesterone and HMOX-1 promote fetal growth by CD8+ T cell modulation. Journal of Clinical Investigation 125 1726-1738. (https://doi.org/10.1172/ JCI68140)

Stoll C, Alembik Y \& Dott B 2003 Limb reduction defects in the first generation and deafness in the second generation of intrauterine exposed fetuses to diethylstilbestrol. Annales de Genetique 46 459-465.

Strahl BD \& Allis CD 2000 The language of covalent histone modifications. Nature 403 41-45. (https://doi.org/10.1038/47412)

Sun L, Goff LA, Trapnell C, Alexander R, Lo KA, Hacisuleyman E, Sauvageau M, Tazon-Vega B, Kelley DR, Hendrickson DG, et al. 2013 Long noncoding RNAs regulate adipogenesis. PNAS 110 3387-3392. (https://doi.org/10.1073/pnas.1222643110)

Sun C, Denisenko O, Sheth B, Cox A, Lucas ES, Smyth NR \& Fleming TP 2015 Epigenetic regulation of histone modifications and Gata 6 gene expression induced by maternal diet in mouse embryoid bodies in a model of developmental programming. BMC Developmental Biology 15 3. (https://doi.org/10.1186/s12861-015-0053-1)

Sun W, Dong H, Becker AS, Dapito DH, Modica S, Grandl G, Opitz L, Efthymiou V, Straub LG, Sarker G, et al. 2018 Cold-induced epigenetic programming of the sperm enhances brown adipose tissue activity in the offspring. Nature Medicine 24 1372-1383. (https://doi. org/10.1038/s41591-018-0102-y)

Susser E, Hoek HW \& Brown A 1998 Neurodevelopmental disorders after prenatal famine: the story of the Dutch famine study. American Journal of Epidemiology 147 213-216. (https://doi.org/10.1093/ oxfordjournals.aje.a009439)

Suter MA, Ma J, Vuguin PM, Hartil K, Fiallo A, Harris RA, Charron MJ \& Aagaard KM 2014 In utero exposure to a maternal high-fat diet alters the epigenetic histone code in a murine model. American Journal of Obstetrics and Gynecology 210 463.e1-463.e11. (https://doi. org/10.1016/j.ajog.2014.01.045)

Swan SH 2000 Intrauterine exposure to diethylstilbestrol: long-term effects in humans. Acta Pathologica, Microbiologica, et Immunologica Scandinavica 108 793-804.

Tahiliani M, Koh KP, Shen Y, Pastor WA, Bandukwala H, Brudno Y, Agarwal S, Iyer LM, Liu DR, Aravind L, et al. 2009 Conversion of 5-methylcytosine to 5-hydroxymethylcytosine in mammalian DNA by MLL partner TET1. Science 324 930-935. (https://doi.org/10.1126/ science.1170116)

Thienpont B, Steinbacher J, Zhao H, D'Anna F, Kuchnio A, Ploumakis A, Ghesquiere B, Van Dyck L, Boeckx B, Schoonjans L, et al. 2016 Tumour hypoxia causes DNA hypermethylation by reducing TET activity. Nature 537 63-68. (https://doi.org/10.1038/nature19081)

Thurner S, Klimek P, Szell M, Duftschmid G, Endel G, Kautzky-Willer A \& Kasper DC 2013 Quantification of excess risk for diabetes for those born in times of hunger, in an entire population of a nation, across a century. PNAS 110 4703-4707. (https://doi.org/10.1073/ pnas.1215626110)

Torrens C, Brawley L, Anthony FW, Dance CS, Dunn R, Jackson AA, Poston L \& Hanson MA 2006 Folate supplementation during pregnancy improves offspring cardiovascular dysfunction induced by protein restriction. Hypertension 47 982-987. (https://doi. org/10.1161/01.HYP.0000215580.43711.d1)

Van Winkle LJ \& Ryznar R 2018 Can uterine secretion of modified histones alter blastocyst implantation, embryo nutrition, and transgenerational phenotype? Biomolecular Concepts 9 176-183. (https://doi.org/10.1515/bmc-2018-0017)

Vehaskari VM, Aviles DH \& Manning J 2001 Prenatal programming of adult hypertension in the rat. Kidney International $59238-245$ (https://doi.org/10.1046/j.1523-1755.2001.00484.x)

Vickaryous N \& Whitelaw E 2005 The role of early embryonic environment on epigenotype and phenotype. Reproduction, Fertility, and Development 17 335-340. https://joe.bioscientifica.com https://doi.org/10.1530/JOE-19-0009 (c) 2019 Society for Endocrinology Published by Bioscientifica Ltd. Printed in Great Britain 
Vickers MH, Breier BH, Cutfield WS, Hofman PL \& Gluckman PD 2000 Fetal origins of hyperphagia, obesity, and hypertension and postnatal amplification by hypercaloric nutrition. American Journal of Physiology: Endocrinology and Metabolism 279 E83-E87. (https://doi.org/10.1152/ ajpendo.2000.279.1.E83)

Voglova K, Bezakova J \& Herichova I 2016 Progress in micro RNA focused research in endocrinology. Endocrine Regulations 50 83-105. (https:// doi.org/10.1515/enr-2016-0012)

Watson CJ, Collier P, Tea I, Neary R, Watson JA, Robinson C, Phelan D, Ledwidge MT, Mcdonald KM, Mccann A, et al. 2014 Hypoxia-induced epigenetic modifications are associated with cardiac tissue fibrosis and the development of a myofibroblast-like phenotype. Human Molecular Genetics 23 2176-2188. (https://doi.org/10.1093/hmg/ddt614)

Wilkins JF 2005 Genomic imprinting and methylation: epigenetic canalization and conflict. Trends in Genetics 21 356-365. (https://doi. org/10.1016/j.tig.2005.04.005)

Wilkins JF 2006 Tissue-specific reactivation of gene expression at an imprinted locus. Journal of Theoretical Biology 240 277-287. (https:// doi.org/10.1016/j.jtbi.2005.09.007)

Williams KT, Garrow TA \& Schalinske KL 2008 Type I diabetes leads to tissue-specific DNA hypomethylation in male rats. Journal of Nutrition 138 2064-2069. (https://doi.org/10.3945/jn.108.094144)

Wolffe AP \& Matzke MA 1999 Epigenetics: regulation through repression. Science 286 481-486.

Wouters-Tyrou D, Martinage A, Chevaillier P \& Sautiere P 1998 Nuclear basic proteins in spermiogenesis. Biochimie 80 117-128.
Yajnik CS 2014 Transmission of obesity-adiposity and related disorders from the mother to the baby. Annals of Nutrition and Metabolism 64 (Supplement 1) 8-17. (https://doi. $\operatorname{org} / 10.1159 / 000362608)$

Yan S \& Jiao K 2016 Functions of miRNAs during mammalian heart development. International Journal of Molecular Sciences 17 E789. (https://doi.org/10.3390/ijms17050789)

Yang X, Han H, De Carvalho DD, Lay FD, Jones PA \& Liang G 2014 Gene body methylation can alter gene expression and is a therapeutic target in cancer. Cancer Cell 26 577-590. (https://doi.org/10.1016/j. ccr.2014.07.028)

Young LE, Fernandes K, Mcevoy TG, Butterwith SC, Gutierrez CG, Carolan C, Broadbent PJ, Robinson JJ, Wilmut I \& Sinclair KD 2001 Epigenetic change in IGF2R is associated with fetal overgrowth after sheep embryo culture. Nature Genetics 27 153-154. (https://doi. org/10.1038/84769)

Zheng S, Rollet M \& Pan YX 2011 Maternal protein restriction during pregnancy induces CCAAT/enhancer-binding protein (C/EBPbeta) expression through the regulation of histone modification at its promoter region in female offspring rat skeletal muscle. Epigenetics 6 161-170. (https://doi.org/10.4161/epi.6.2.13472)

Zucchi FC, Yao Y, Ward ID, Ilnytskyy Y, Olson DM, Benzies K, Kovalchuk I, Kovalchuk O \& Metz GA 2013 Maternal stress induces epigenetic signatures of psychiatric and neurological diseases in the offspring. PLOS ONE 8 e56967. (https://doi.org/10.1371/journal. pone.0056967)

Received in final form 16 April 2019 Accepted 23 April 2019 (c) 2019 Society for Endocrinology Published by Bioscientifica Ltd. 